\title{
As TeOrias da Linguagem EM Lacan
}

Bianca Novaes de Mello

A partir da oposição entre modelos de linguagem que reduzem seu objeto às leis internas ao sistema da língua e modelos que abarcam a posição dos falantes e o contexto discursivo, buscamos verificar qual concepção de linguagem Lacan usa quando teorizando sobre a linguagem na experiência analítica. A fim de demarcar a especificidade do campo psicanalítico, cotejamos a noção de linguagem em Lacan com o modelo estruturalista e com a filosofia pragmática da linguagem.

BANCA:

Ana Maria Rudge (Orientadora)

Ana Beatriz Freire

Anna Carolina Lo Bianco Clementino

Francisco Moacir de Melo Catunda Martins

Roberto Pires Calazans Matos

Data da defesa: $12 / 03 / 2010$ 